\title{
Comment \\ Comment on Seibert, M.K.; Rees, W.E. Through the Eye of a Needle: An Eco-Heterodox Perspective on the Renewable Energy Transition. Energies 2021, 14, 4508
}

\author{
Vasilis Fthenakis ${ }^{1,2, *}$, Marco Raugei ${ }^{1,3,4}(\mathbb{D})$, Christian Breyer ${ }^{5}\left(\mathbb{D}\right.$, Suby Bhattacharya ${ }^{6}\left(\mathbb{D}\right.$, Michael Carbajales-Dale ${ }^{7}$, \\ Michael Ginsberg ${ }^{1}$, Arnulf Jäger-Waldau ${ }^{8} \mathbb{D}$, Enrica Leccisi ${ }^{1}{ }^{(D}$, Daniel Lincot ${ }^{9}$, David Murphy ${ }^{10}$, \\ Marc J. R. Perez ${ }^{11}$, Parikhit Sinha ${ }^{12} \mathbb{D}$, Angus Rockett ${ }^{13} \mathbb{D}$, Sascha Sadewasser ${ }^{14}$, Billy J. Stanbery ${ }^{15} \mathbb{D}$, \\ Richard M. Swanson ${ }^{16}$ and Pierre Verlinden ${ }^{17,18,19}$ (D)
}

check for updates

Citation: Fthenakis, V.; Raugei, M.; Breyer, C.; Bhattacharya, S.;

Carbajales-Dale, M.; Ginsberg, M.; Jäger-Waldau, A.; Leccisi, E.; Lincot, D.; Murphy, D.; et al. Comment on SSeibert, M.K.; Rees, W.E. Through the Eye of a Needle: An Eco-Heterodox Perspective on the Renewable Energy Transition. Energies 2021, 14, 4508. Energies 2022, 15,971. https://doi.org/10.3390/ en15030971

Academic Editor: Abdul-Ghani Olabi

Received: 12 November 2021

Accepted: 21 December 2021

Published: 28 January 2022

Publisher's Note: MDPI stays neutral with regard to jurisdictional claims in published maps and institutional affiliations.

Copyright: (c) 2022 by the authors. Licensee MDPI, Basel, Switzerland. This article is an open access article distributed under the terms and conditions of the Creative Commons Attribution (CC BY) license (https:// creativecommons.org/licenses/by/ $4.0 /)$.
1 Center for Life Cycle Analysis, School of Engineering and Applied Science, Columbia University, New York, NY 10027, USA; marco.raugei@brookes.ac.uk (M.R.); mg3217@columbia.edu (M.G.); el2828@columbia.edu (E.L.)

2 Brookhaven National Laboratory, Interdisciplinary Sciences Department, Building 815, Upton, NY 11973, USA

3 School of Engineering, Computing and Mathematics, Faculty of Technology, Design and Environment, Oxford Brookes University, Wheatley Campus, Oxford OX3 0BP, UK

4 Ricardo plc, 30 Eastbourne Terrace, London W2 6LA, UK

5 School of Energy Systems, LUT University, 53850 Lappeenranta, Finland; christian.breyer@lut.fi

6 Civil and Environmental Engineering Department, University of Surrey, Guildford GU2 7XH, UK; s.bhattacharya@surrey.ac.uk

7 Environmental Engineering \& Earth Sciences, Clemson University, Clemson, SC 29634, USA; madale@clemson.edu

8 European Commission, Joint Research Centre, 21014 Ispra, Italy; arnulf.jaeger-waldau@ec.europa.eu

9 Institut Photovoltaïque d'Île de France (IPVF), CNRS UMR 9006, 18 Boulevard Thomas Gobert, 91120 Palaiseau, France; daniel.lincot@cnrs.fr

10 Environmental Studies Department, St. Lawrence University, Canton, NY 13617, USA; dmurphy@stlawu.edu

11 Clean Power Research, 1541 3rd Street, Napa, CA 94559, USA; marcp@cleanpower.com

12 First Solar, 350 W Washington St., Tempe, AZ 85281, USA; Parikhit.Sinha@firstsolar.com

13 Angus Rockett, Department of Metallurgical and Materials Engineering, 305b Hill Hall, Colorado School of Mines, 1500 Illinois St., Golden, CO 80401, USA; arockett@mines.edu

14 INL-International Iberian Nanotechnology Laboratory, Av. Mestre José Veiga s/n, 4715-330 Braga, Portugal; Sascha.Sadewasser@inl.int

15 HelioSourceTech, 8987 E. Tanque Verde, Suite 309, PMB216, Tucson, AZ 85749, USA; bjs@heliosourcetech.com

16 Sunpower Founder, Retired, 24700 Voorhees Drive, Los Altos Hills, CA 94022, USA; dickswanson15@gmail.com

17 AMROCK Group, Sydney, NSW 2052, Australia; pjverlinden@icloud.com

18 School of Photovoltaic \& Renewable Energy Engineering, University of New South Wales, Sydney, NSW 2052, Australia

19 State Key Laboratory of PVST, Trina Solar, Xinbei District, Changzhou 213031, China

* Correspondence: vmf5@columbia.edu

Abstract: This paper exposes the many flaws in the article "Through the Eye of a Needle: An Ecoheterodox Perspective on the Renewable Energy Transition, authored by Siebert and Rees and recently published in Energies as a Review. Our intention in submitting this critique is to expose and rectify the original article's non-scientific approach to the review process that includes selective (and hence biased) screening of the literature focusing on the challenges related to renewable energies, without discussing any of the well-documented solutions. In so doing, we also provide a rigorous refutation of several statements made by a Seibert-Rees paper, which often appear to be unsubstantiated personal opinions and not based on a balanced review of the available literature.

Keywords: renewables; solar; wind; sustainability; resources; challenges 


\section{Introduction}

According to Seibert and Rees, their recently published Review paper entitled "Through the Eye of a Needle: An Eco-Heterodox Perspective on the Renewable Energy Transition" [1] highlights "numerous collectively fatal problems with so-called renewable energy technologies" and "makes clear that the pat notion of affordable clean energy views the world through a narrow keyhole that is blind to innumerable economic, ecological and social costs".

The renewable energy ( $\mathrm{RE}$ ) research community understands that assessing the sustainability of the rapid growth of RE necessitates the undertaking of a careful analysis because RE markets are largely enabled by its promise to produce reliable electricity with minimum environmental burdens. It is extremely important that, as humanity embarks on a necessary energy transition from clearly unsustainable sources such as fossil fuels (FFs), it does so while examining both positive and potentially negative impacts of alternative scenarios. Careful, level-headed thought on the implications of this transition is in order; the RE research community has conducted numerous studies over the last two decades addressing such implications, solutions and remaining challenges and a selection of these studies are cited in Section 2 below, as appropriate.

Unfortunately, Siebert and Rees did not reference any of these studies, but instead they chose to cherry-pick a few sources that exaggerated potential impacts and selectively quoted statements that do not represent the current scientific consensus at all, in order to advocate a drastic behavioral change and population reduction.

There is in fact broad agreement that both technological and behavioral solutions will be needed to achieve rapid decarbonization (or rather, "defossilization", i.e., freedom from the dependence on fossil carbon resources) and denigrating one approach to advance the other is self-defeating. Regardless of the speed at which the energy transition occurs, the more climate change mitigation that is achieved by a combination of technological and behavioral solutions, the less adaptation will be needed [2], making the authors' "eye of the needle" analogy less relevant. In addition, while some of the more general, high-level points made by the authors can, to some degree, be agreed upon, this is no excuse for their lack of due diligence, or for in fact perpetrating false myths. Since the Siebert and Rees paper was published as a Review, not an Opinion paper, this commentary shall be constrained to rebutting their major flaws in reviewing RE technologies.

\section{Statements in the Seibert-Rees (S-R) Paper and Counter-Arguments}

In Section 3, "Problems with So-Called Renewables", Seibert and Rees state that the "espoused technologies are not renewable, that their production-from mining to installation-is fossil-energy-intensive" and that "producing them-particularly mining their metals and discarding their waste - entails egregious social injustices and significant ecological degradation". In addition, they state that "Green New Deal (GND) proponents are appallingly tolerant of the inexplicable. They fail to address how the gigatons of already severely depleted metals and minerals essential to building so-called RE technologies will be available in perpetuity considering typical five to 30-year life spans and the need for continuous replacement [3-5]. They offer no viable workarounds for the ecological damage and deplorable working conditions, often in the Global South, involved in metal ore extraction [6,7]. The waste streams generated by so-called renewables at the end of their short working lives are either ignored or assumed away, to be dealt with eventually by yet non-existent recycling processes [8-10]".

Let us first stress that the phrase "so-called renewables" is misleading and fundamentally wrong from a scientific point of view. Solar energy is in fact renewable for all intents and purposes, as the rate of consumption of Hydrogen in the nuclear fusion reaction in the Sun is negligible on the human time scale. In addition, most of the materials used to produce the solar modules will still be recoverable at the end of their service life, rendering photovoltaic electricity as a whole effectively renewable to a very large degree. Therefore, the authors' systematic use of the phrase "so called renewables" comes across as a deliberate attempt to elicit a negative perception in the reader, lacking proper discussion. 
Then, it is noteworthy that none of the papers cited to support such a viewpoint support the conclusions the authors propose as "final", namely that the solution to the raised problems is to "reduce the global population to the one billion or so people that can thrive sustainably in reasonable material comfort within the constraints of a non-fossil energy future" and stop the development of RE except for wood, biomass, and mechanical wind energy. Actually, Vidal et al. [3] note the increasing demand for metals and other resources in RE, but they offer solutions to such in the form of "green mining" operations in Europe that can become prototypes in global development. Sovacool $[6,7]$ reports alarming cases of forced labor in Africa and mafia-like operations in Latin America, but concludes that "ample opportunities exist to make low-carbon world more pluralistic, demographic and just". The S-R's statement that the "end of their short working lives are either ignored or assumed away, to be dealt with yet non-existent recycling technologies" is even more elusive as their own references [8-10] do not support this argument. Chowdhary et al. [8] reviews several PV recycling technologies and highlights the need for recycling to become obligatory worldwide (it is already obligatory in the EU and solar modules are about to be included in a revision of the European Union's Eco-design Directive (Directive 2009/125/EC)). $\mathrm{Xu}$ et al. [9] provide a quantitative basis to support the recycling of PV panels. Liu and Barlow [10] admit that the recycling of the blades of wind turbines is still in development and estimate what the demand for recycling will be in the future, more or less the opposite of "ignored" or "assumed away."

Even more importantly, Siebert and Rees neither discussed nor cited any of the hundreds of peer-review articles that acknowledged the aforementioned challenges and documented quantitative solutions. For example, the availability of "critical materials" needed for building a very large RE infrastructure has been addressed by the European Commission (EC) [11], the US Department of Energy (DoE) [12], and the US Geological Survey [13].

Academic research addressing key potentially criticalities in 100\% RE scenarios [14] identified several critical materials, but did so in a constructive rather than destructive fashion, as shown for Lithium [15], Neodymium and Dysprosium [16], Cobalt through the current phase-in of Cobalt-free batteries [17] and for solar PV in the scale of up to 170 TW total installed capacity towards the end of the century [18], a capacity target which is independently confirmed by a second research team [19].

It is widely recognized that individual photovoltaic (PV) technologies would experience material challenges for reaching very high levels of production, but such sustainability challenges do not appear before any technology reaches multi-GW annual production and multi-TW cumulative production. For example, CdTe PV is constrained by Te availability, but there is enough Te available from Copper anode slimes to support at least 4-5 times current production capacity [20] and cumulative TW-scale production by 2050 [21]. Similar constraints apply to In and Ga for CIGS PV, Ag for c-Si PV, and Cu for cables. However, a recent collective study on Indium showed that Indium availability is in fact not a limiting factor for sustaining large scale production of CIGS PV [22]. The authors show the feasibility of reducing the amount of critical materials in the devices for the same efficiency output, by reducing the thickness of the photoactive layers, or using microcells under light concentration [23]. In addition, in the case of Silver for c-Si PV, Ag is not actually an essential component for the PV cells, and it can be progressively replaced by more abundant metals, like $\mathrm{Cu}$.

In a more general view, material availability and costs are metrics that are taken into consideration in the selection of individual technologies, and this is why the RE future is widely seen as comprising many RE technologies, which, when taken together, will be amply sufficient for providing the multi-hundred TW of RE installations needed worldwide by 2050-2100 [24-35]. In addition, metal mining and refining can be organized in a 100\% RE environment, as showcased for the global Copper industry [36].

In Section 3.1.1, "Big Picture sanity check", the authors state that "Transitioning the U.S. electrical supply away from FFs [fossil fuels] by 2050 would require a grid construction rate 14 times that of the rate over the past half century [37]. The actual installed costs for a global solar 
program would have totaled roughly $\$ 252$ trillion (about 13 times the U.S. GDP) a decade ago [38] and considerably more today".

It is appalling that the references cited here $[37,38]$ are unsubstantiated, non-peerreviewed reports from known climate change deniers; Siebert and Rees did not cite the US DoE SunShot Studies [39-41], which—in each edition since 2000-have been proven to be correct in their forecasting. The educated result from the DoE studies is that such transitioning will cost less than one trillion US\$; a leading study published in Scientific American and Energy Policy 12 years ago estimated the total cost of increasing the penetration of RE into the US grid to $69 \%$ by 2050 at only 450 billion [42,43]. Other recent reports indicate how absurd the $\$ 252$ trillion estimate really is. Even the recently published "Net Zero America" [44] report, a widely publicized non-peer-reviewed analysis of the energy transition by scholars at Princeton University, estimates that $\$ 2.5$ trillion over the next decade would be needed in additional investments and that would be across all sectors involved in the energy transition (e.g., electricity grid, EVs and all other RE technologies). This is still roughly $100 \times$ smaller than the Siebert and Rees figure. Additionally, a recent report from researchers at the Institute for New Economic Thinking suggested that the cost of a transition to clean energy from renewables is likely to be much less expensive than the 'business as usual' pathway, without any substantial reduction in reliability [45]. Bogdanov et al. [46] show that the ratio of the total annualized energy system cost to the final energy demand of the entire North America can gradually decline while transitioning towards $100 \%$ RE by 2050, along a continued energy transition process. Earlier research concluded that a North American power system integration with Canada and Mexico would create further benefits and cost reductions for 100\% RE supply [47], while an energy system integration across all Americas would be of limited additional benefit [48].

In the same section, Siebert and Rees go on to state that "the United States would have to quadruple its last annual construction of wind turbines every year for the next 15 years and triple its last annual construction of solar PV every year for the next 15 years-only to repeat the process indefinitely since solar panels and wind turbines have average lifespans of around 15 to 30 years [49,50]".

However, the cited reports actually specify the minimum expected lifespans of solar panels to be 25-30 years (not 15 years), and it is noted that modules are sold with a guaranteed power performance of 25 years and are expected to function even longer than 30 years.

The authors then say, "In addition, Clack et al. [51] found that one of the most cited studies on $100 \%$ electrification in the United States is error-prone and laden with untenable assumptions". Indeed, Clack et al. criticized the Jacobson et al. study, but the criticism was limited to methodological issues and not the notion of $100 \%$ RE scenarios per se. In addition, that was not the last word in the debate as Clack et al.'s criticism was rebuffed by other scholars [52]. Additionally, at least 56 peer-reviewed papers among 18 independent groups found $100 \%$ RE possible at low cost in different parts of the world [53], and, in later publications, an overview on 180 studies on 100\% RE has been provided [54] and as of June 2021 at least 550 studies on $100 \%$ RE have been recorded [19]. There are also peer-reviewed papers that directly address the critics of $100 \%$ RE scenarios $[55,56]$, but Siebert and Rees did not cite any of these.

In Section 3.1.2, "Heat for Manufacturing", the authors' statement that "The manufacturing processes used today to make solar panels, high-tech wind turbines, batteries and all other industrial products involve very high temperatures that are currently generated using FFs" appears to imply that the benefit of transitioning to RE is defeated by the fact that RE systems themselves require fossil fuels for their manufacturing. Firstly, such statement is misleading because it fails to take into account and compare the different orders of magnitudes involved. Even when the thermal energy required for the manufacturing of RE technologies is primarily supplied by FFs, the overall amount of fossil energy used per unit of delivered energy output is orders of magnitude lower than the amount currently used to generate the same useful energy using conventional technologies. This has been 
proven beyond any doubt by countless quantitative life cycle assessments (LCA) in the literature, e.g., [57-74]. Secondly, the same statement also incorrectly implies that RE cannot supply the high temperatures used in RE manufacturing. However, the high temperature processes in the life cycle of PV panels are powered by electricity, not directly by fossil fuels; there is no fossil fuel input connection, for instance, to a Siemens reactor for the production of semiconductor- and solar-grade Silicon or to the sub-atmospheric semiconductor deposition chambers used in any of the various PV technologies [57]. In fact, the overwhelming majority, around $80-90 \%$, of energy inputs to the manufacture of solar PV come in the form of electricity, meaning that solar energy could be self-sustaining [75].

The authors then state "more energy is required to produce and compress the product (Hydrogen) than it can later generate [38,76-78]". However, of course, this can be said for ANY energy storage technology, otherwise one would have created a perpetual motion machine, which violates the second law of thermodynamics! Furthermore, the citations they have listed do not support the affirmation that "there is scant information on whether or how it can be generated with RE alone". Firedmann et al. [76], for instance, concludes that "Hydrogen-based industrial heat provides an actionable pathway to start industrial decarbonization at once, particularly in the petrochemical, refining and glass sectors, while over time reducing cost and contribution of fossil sources" [76]. Recent research on the role of Hydrogen [32] clearly indicates that first of all a comprehensive electrification of all energy services has to be the central aim; however, the remaining segments, which cannot be directly electrified, can be tackled for zero greenhouse gas (GHG) emissions with solutions typically based on Hydrogen. The required Hydrogen can be fully based on renewable electricity. This applies to Hydrogen-based steel [79], chemicals [80,81], further high-temperature industrial processes and long-distance marine and aviation transportation. In case Hydrogen-based solutions are used for applications which cannot be directly electrified, then this can be part of a cost-neutral energy transition [46].

Furthermore, the authors say, "The only viable, large-scale feedstock for Hydrogen is natural gas and the gas reforming process requires temperatures ranging from $1300^{\circ} \mathrm{F}$ to $1830^{\circ} \mathrm{F}$ $\left(700^{\circ} \mathrm{C}\right.$ to $\left.1000^{\circ} \mathrm{C}\right)[38,77,78,82]^{\prime \prime}$. The authors did not list any of the hundreds of articles dealing with the production of "green $\mathrm{H}_{2}$ " by using $\mathrm{RE}$ to power water electrolyzers; electrolytic $\mathrm{H}_{2}$ currently costs 2-3 times more than $\mathrm{SMR} \mathrm{H}_{2}$, but its learning curve shows that cost parity is being approached quickly. Recent studies on optimizing electrolyzer operation to follow electricity pricing patterns show that the levelized cost of Hydrogen can get as low as to $\$ 2 / \mathrm{kg}\left(\mathrm{H}_{2}\right)$ with dynamic operation following simple enhancements in electrolyzer components [83]. This is supported by an IRENA 2019 analysis showing that Hydrogen produced from electricity can be competitive if the price of electricity falls to below USD 30/MWh, which is projected with increased solar energy penetration [84]. Global-local analyses for hybrid PV-wind based green Hydrogen indicates huge and lowcost upcoming Hydrogen potential all over the world [85]. Latest cost-optimized green Hydrogen for large utility-scale applications indicates that there is cost parity of green Hydrogen and $\mathrm{SMR} \mathrm{H}_{2}$ for the best solar resource regions and broad cost parity is expected worldwide by 2030 [86]. Furthermore, electrolyzer cost competitiveness is largely limited by policy obstacles that prevent electrolyzer participation in the wholesale electricity market [87]. Currently, electrolyzers are treated as industrial electricity consumers as opposed to wholesale market participants with exposure to low-priced solar energy. In the USA, access will be provided under Federal Energy Regulatory Commission (FERC) Order n. 2222, which will also open electrolyzers to additional revenue streams as dispatchable loads from the provision of ancillary grid services, such as demand response and congestion alleviation [88,89]. In an analysis using approximately 7000 actual electricity utility rates, an NREL study found that electrolysis-based Hydrogen production costs are already cost competitive and that dynamic rates and optimal sizing further reduce cost [90]. In addition, regardless of the price dynamics involved and whether or not price parity is reached between the technologies, the outright omission of any reference to the vast body of literature discussing green $\mathrm{H}_{2}$ is misleading at best. 
In addition, the authors claim that "The only potential replacement for coal is charcoal derived from wood". First of all, the authors' claim is of dubious validity due to the fact that it remains unproven, and, in fact, it is highly doubtful that enough wood could be sustainably harvested to even come close to replacing fossil coal in all industrial applications. Coal in the industry sector is mainly used for steelmaking and in the cement and chemical industries [91]. For these industries, renewable electricity-based solutions are instead available and are likely to see commercialization in this decade [79-81,92,93]. It has been shown that an energy-industry system based on 100\% RE can fully phase out coal while reducing energy system cost and being stable for all hours of a year [94].

Section 3.1.3, "Problems with Solar Panels" is flawed in its entirety. The authors did a very good job of selectively finding and citing a handful of anti-solar articles that exist in the literature, while carefully avoiding to cite any of the hundreds of articles that show the evolution of the PV industry regarding increasing efficiencies, improving material utilization and reducing and controlling emissions. There are even meta-analyses of solar PV (and other renewable energy technologies) that have tracked reductions in environmental impacts throughout the lifetime of the industry $[26,58,95,96]$. In their assertion that "solar panel uses toxic substances, large quantities of energy and produces toxic byproducts [38,97]" they cited a report based on the premise that "we don't have an energy crisis, we have a consumption crisis" and a 2014 commentary alluding to actual episodes of Silicon Tetrachloride dumping in the early days of solar Silicon manufacturing in China, but without mentioning the epilogue of the commentary where the author noted the value of the environmental, health and safety (EH\&S) studies by the National PV Environmental Research Center at Brookhaven National Laboratory [98-114] and the emerging, at the time, programs from major PV companies to prevent and control emissions in manufacturing.

The most impactful action that industries involved in PV recycling could take is to assume Extended Producer Responsibility (EPR) following the European initiative. Recycling end-of life systems then becomes an important aspect of sustainability and needs to be optimized to help, rather than hinder, the affordability of photovoltaic systems.

Seibert and Rees also state: "The much-touted silver bullet of recycling is not the panacea is it purported to be. Recycling requires copious amounts of energy, water and other inputs and exposes workers to toxic materials that have to be disposed".

Both thermodynamics and engineering practice have shown beyond a reasonable doubt that, in virtually all cases, recycling saves energy, water, and valuable materials, while reducing environmental impacts such as such as freshwater eutrophication, human toxicity, terrestrial acidification, and this is also demonstrated as being the case for photovoltaics [115-127]. Recycling of PV in Europe is regulated by the Waste Electrical and Electronic Equipment (WEEE) directive [128,129]; in addition, recycling facilities already take up all the rejects and waste from CdTe PV manufacturing and deployment [130]. Recycling technologies have been demonstrated for all commercial PV technologies; however, recycling infrastructure needs to be built to handle the large volumes of end-of-life PV down the road. The same challenge applies to solar glass, for which a capacity two times higher than the current capacity would be needed by 2030 to handle projected PV manufacture scaling-up [131]. However, the PV industry has proved in the past that it is well-equipped to rather quickly react to such market demands; this is illustrated by the multifold increase of solar silicon production between 2004 and 2008, as the supply from the rejects of the semiconductor grade silicon proved to be insufficient.

Finally, Seibert and Rees devoted just one sentence to the very important topic of Energy Return on Energy Investment (EROI or EROEI); they claimed that "even without such drawbacks, solar PV has a low energy return on energy invested (EROEI) - too low to power modern civilization [131-134]".

Again, the authors selected from an extensive literature on life cycle analysis three articles and a report from fossil fuel advocates. De Castro's PV EROI calculations [132,133] appear to be based on 30-year-old data corresponding to $400 \mu \mathrm{m}$-thick Silicon wafers and cement platform foundations of low efficiency photovoltaics in low irradiation regions 
and the worst conditions of severe weather during installations. Ferroni et al. [134] and Prieto et al. [135] used flawed methodologies with double counting and unbalanced boundary systems between fossil fuel and solar technologies. These two studies have been amply rebuffed $[59,60]$, but Seibert and Rees did not present the papers that corrected the ones selectively cited, nor did they cite other independent studies pointing out that a renewable energy-based society can deliver the EROI required for long-term stability [62-69].

Seibert and Rees apparently did not examine the literature on EROI [62-69] and did not understand the associated context. Any postulation of a 'minimum' EROI that is supposedly required to support "modern civilization" is problematic, unless the same system boundaries may be reasonably assumed to remain in place consistently across the board of the energy resources being compared, which-critically-would have to include a common 'point of use'. However, this is clearly not the case. Instead, as already discussed elsewhere [70], "the requirement for a relatively high 'minimum' overall EROI has historically been due to the necessity to transport and refine (by means of additional energy investments) a mix of conventional fuels, before they are put to use in a range of unavoidably inefficient thermal processes, which are all ultimately limited by Carnot's principle. However, when looking at the future, part of the appeal of a major energy transition (besides the environmental benefits in terms of reduced carbon emissions and pollution) is precisely to side-step such inherent supply chain and conversion efficiency limitations, essentially by pushing for more electrification in all sectors, while producing a large share of this electricity using low-carbon, renewable resources [56]. A significantly lower 'minimum' EROI may therefore well suffice to support such a fundamentally different future society relying on renewable electricity for a larger share of its energy metabolism".

As shown in Figures 1 and 2, the energy pay-back time (EPBT) of PV systems has improved by an order of magnitude during 1990-2010 and by almost a factor of 2 during 2015-2020 [58,63-69,72-74]. The latest peer-reviewed LCA calculations $[58,63]$ indicate that, for mono-crystalline Si PV systems, it takes from 0.6 to 1.3 years (depending on the assumed irradiation) to return an amount of electricity that is equivalent to the primary energy invested, whereas, for multi-crystalline Si PV it takes from approximately 0.6 to 1.5 years and, for CdTe PV, it takes 0.5 to 1.1 years. This translates to EROI values between 20 and 50 (Figure 3), when the energy return is expressed in terms of equivalent primary energy (based on an assumed average primary energy-to-electricity conversion efficiency of 0.3$)$.

A recent study estimated that, even when adding up to $4 \mathrm{~h}$ of electrochemical storage to PV, the EPBT of the combined PV + storage system would only increase by $30 \%$ at worst [69], which translates to no more than a $23 \%$ decrease in EROI.

In Section 3.1.4, "Problems with Batteries" S\&R claim that "Storing only $24 \mathrm{~h}$ worth of U.S. electricity generation in lithium batteries would cost \$11.9 trillion". This statement is problematic in two fundamental ways. Firstly, the authors' estimate fails to take into account the rapidly declining trend in the cost of electrochemical storage that has been underway for more than a decade and the fact that such trend is widely expected to continue [136]. Secondly, and even more importantly, the assumption that $24 \mathrm{~h}$ of total U.S. electricity generation would need to be stored is unsubstantiated.

An energy system analysis in full hourly resolution for the entire energy system covering all energy sectors for North America structured in 20 regions [46] found that, for a $100 \%$ RE system in 2050, $1809 \mathrm{GWh}_{\text {cap }}$ of battery capacity would suffice for about $90 \%$ of all electricity storage, for a total electricity generation of 19,200 TWh. This is equivalent to about one hour of average storage, which is enabled by resource complementarity [137], dispatchable renewables (hydropower, bioenergy), grids interconnection, sector coupling, storage and less than 10\% curtailment, while the total energy system cost steadily declines, from the present to 2050. It is also noted that oversizing photovoltaic power plants is a cost-effective way of controlling minute-to-minute solar resource fluctuations and in addition provide grid frequency and voltage stability services [138-140]. 


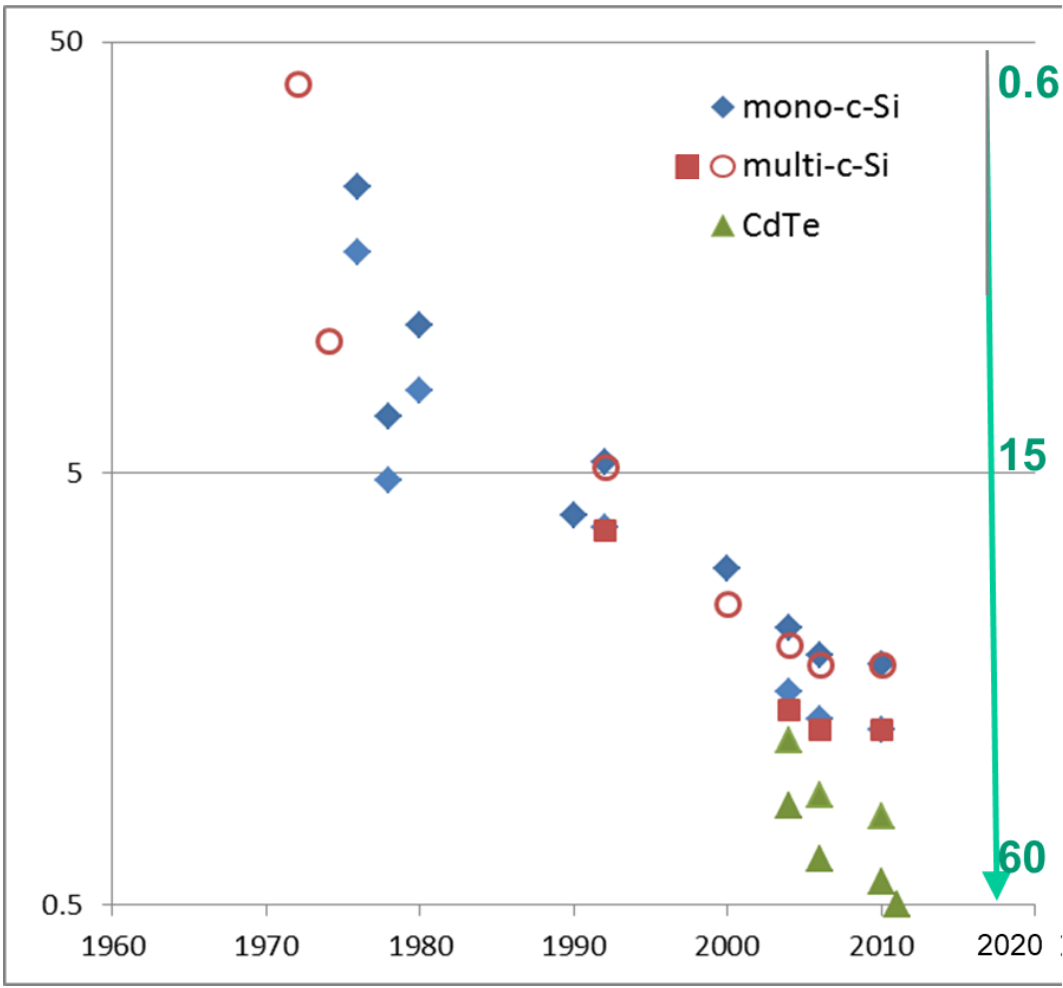

Figure 1. Historical evolution of Energy Payback Times (EPBTs) of PVs, from 50 years down to half a year and corresponding Energy Return to Energy Investment (EROI); published estimates corresponding to insolation of 1700 and $2300 \mathrm{kWh} / \mathrm{m}^{2} /$ year-updated from Fthenakis and Lynn [57].

3
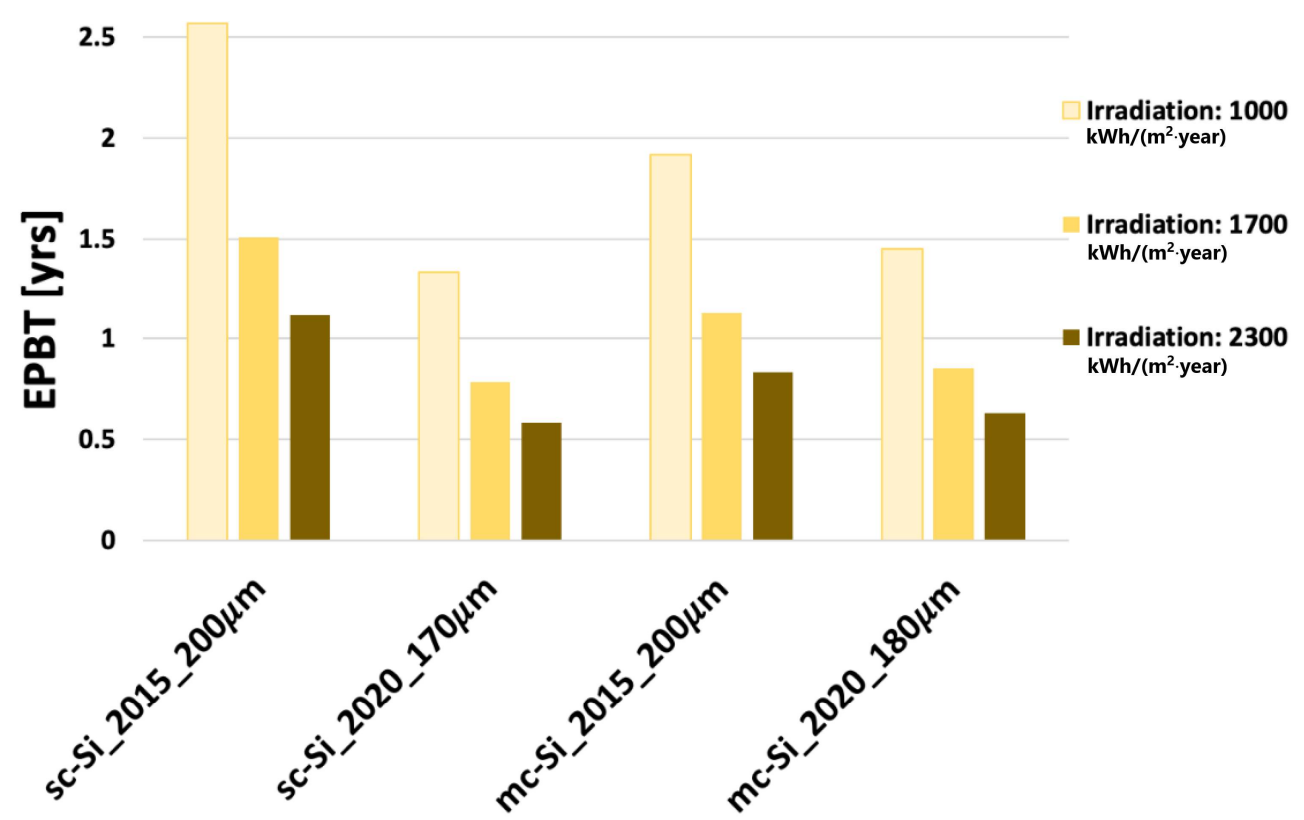

Figure 2. EPBTs reductions from 2015 to 2020, under three irradiation levels: $1000 \mathrm{kWh} /\left(\mathrm{m}^{2} \cdot\right.$ year), $1700 \mathrm{kWh} /\left(\mathrm{m}^{2} \cdot\right.$ year), and $2300 \mathrm{kWh} /\left(\mathrm{m}^{2} \cdot\right.$ year). Performance ratio: 0.85 . Efficiencies: $17 \%$ and $20.5 \%$ for 2015 and 2020 single-crystalline Si (sc-Si) photovoltaic (PV), respectively, and $16 \%$ and 18\% for 2015 and 2020 multicrystalline Si (mc-Si) PV, respectively_from Fthenakis and Leccisi [58]. 


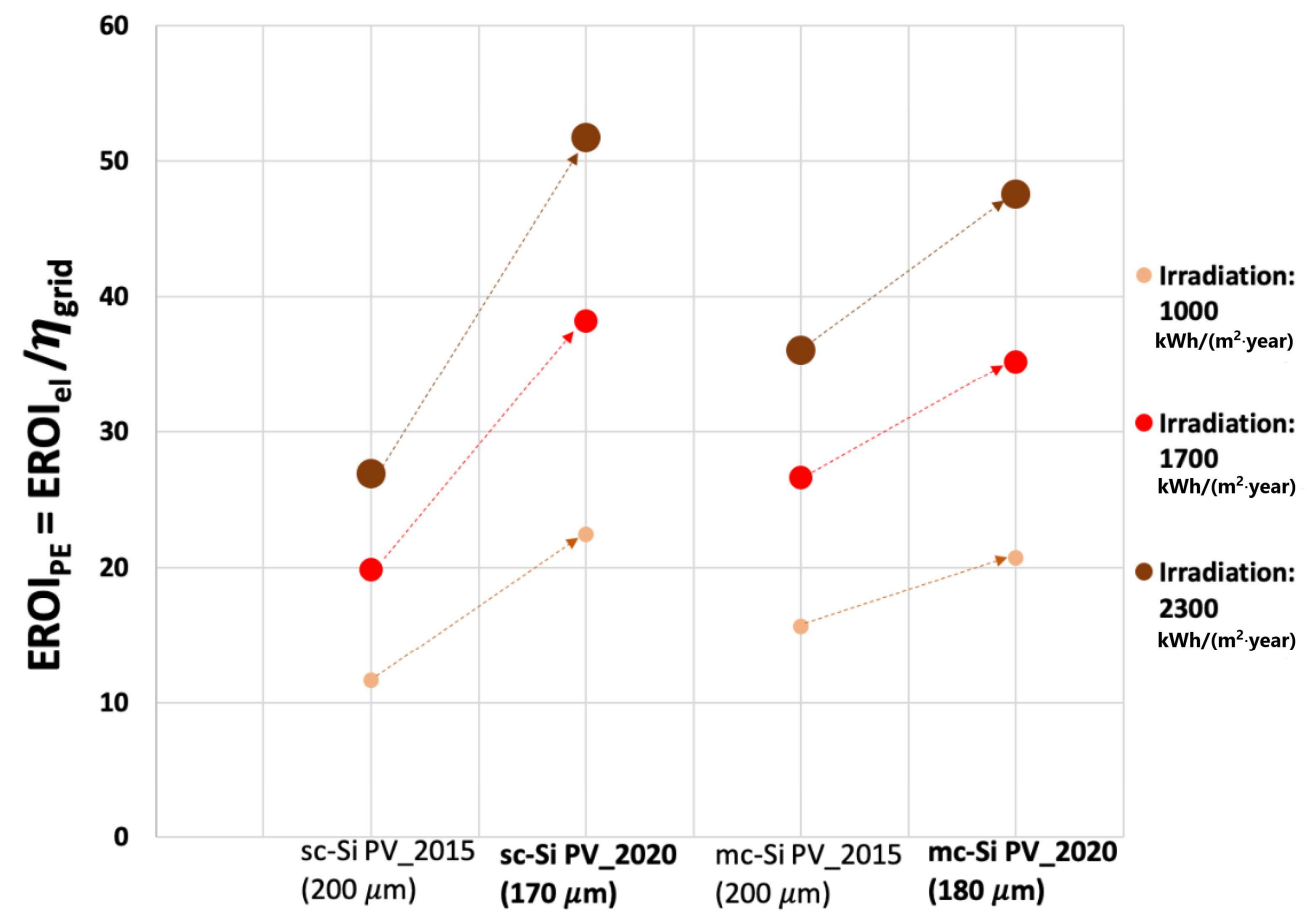

Figure 3. EROIs increases from 2015 to 2020, under three irradiation levels: $1000 \mathrm{kWh} /\left(\mathrm{m}^{2} \cdot\right.$ year), $1700 \mathrm{kWh} /\left(\mathrm{m}^{2}\right.$.year $)$ and $2300 \mathrm{kWh} /\left(\mathrm{m}^{2} \cdot\right.$ year $)$. Assumed $\eta_{\text {grid }}=0.30$; lifetime $=30$ years. Performance ratio: 0.85 . Efficiencies: $17 \%$ and $20.5 \%$ for 2015 and 2020 single-crystalline Si (sc-Si) photovoltaic (PV), respectively, and 16\% and 18\% for 2015 and 2020 multi-crystalline Si (mc-Si) PV, respectively-from Fthenakis and Leccisi [58].

Another recent analysis focusing on California and based on a detailed $1 \mathrm{~h}$-resolution power dispatch model informed by actual historical demand and generation data found that a projected $80 \%$ RE generation mix relying heavily on PV would be capable of meeting the domestic demand profile while only requiring $6 \mathrm{~h}$ of storage capacity [65]. A follow-up study further calculated that a similar amount of storage (in terms of duration) would suffice while also meeting the additional demand created by 10 million EVs on California roads [141].

Seibert and Rees also claimed that heavy-duty trucks could not be powered by batteries; unfortunately for them, the major truck manufacturers in the world are already transforming their production lines to enable an almost entirely battery-powered truck fleet [142-146], as this is the least cost option per driven kilometer. In addition, it is claimed that batteries would have a lifespan of 5 to 15 years, whereas leading manufacturers such as Samsung provide guarantees of 6000 cycles [147], which leads to approximately 20 years of life for about 300 full charge cycles per year, which is equivalent to almost a full charge cycle per day. Battery lifetimes up to 30 years are expected [148].

Furthermore, the text about grid storage focuses entirely on Li-ion battery technologies, ignoring the fact that Li-ion batteries have only gained a major market share since about 10-15 years ago and that other battery technologies (e.g., Na-ion, redox-flow) also present viable options for grid-scale energy storage.

Finally, the authors state that: "Batteries have a life span of around 5 to 15 years, creating an additional, significant waste management problem [6]. They cannot be disposed of in landfills due to their toxicity and are one of the fastest-growing contributors to e-waste streams. Only $5 \%$ of all Lithium batteries are recycled". However, the recycling problem is only starting to become relevant in terms of scale, and the industry is already developing solutions. The currently available pyrometallurgical recycling is proven to provide benefits to the environment [149] and even more efficient hydrometallurgical methods [150] are expected 
to become mainstream in the coming decades [151], when sufficiently large end-of-life quantities enable economies of scale.

Section 3.1.5, "Problems with Wind" picks one single study to claim that the EROI of wind is below 3 , despite numerous meta-analyses which have demonstrated that wind electricity has an EROI greater than 20-even when the numerator of the EROI ratio is expressed in straight units of electricity and obviously even higher EROI values are calculated when the electricity output is instead consistently converted to units of primary energy equivalents [152-154]. While wind does generate some waste products, the largest of these from an energy perspective comes from the steel in the tower, which can be recycled using a process that relies on electricity as its main energy input and which may therefore be decarbonized to a large extent. The use of fossil fuels (and associated carbon emissions) within construction equipment is also not an essential characteristic. Many companies, e.g., Komatsu and Liebherr, are starting to offer battery-electric alternatives, where the mass of the battery is actually beneficial to counterbalance cranes and backhoes. Finally, while there is still the issue of cement, which does entail GHG emissions in its production, wind electricity is still one of the low carbon emitters, with a carbon intensity of around $11 \mathrm{~g}$ $\mathrm{CO}_{2}$-eq per $\mathrm{kWh}$, i.e., orders of magnitude lower than fossil fuel based technologies, even when the latter are equipped with carbon capture and sequestration (CCS) $[155,156]$.

Section 3.1.9, "Problems with Technological Carbon Sequestration" discusses challenges with CCS and direct air capture (DAC) of $\mathrm{CO}_{2}$. It is claimed that "it would cost around $\$ 600$ billion to capture and sequester 1 Gt of carbon [157]". Analyses based on the latest technology characteristics of renewable electricity-based DAC [158] performed in hourly temporal and high geo-spatial resolution for the Maghreb [159] and globally [160] find that, by 2050, $\mathrm{CO}_{2}$ DAC should be possible for about $€ 50$ billion per $\mathrm{Gt}$ of $\mathrm{CO}_{2}$, or less. Nevertheless, CCS has additional sustainability constraints, in particular for the case of bioenergy with CCS (BECCS), which could be overcome by applying DAC-based CCS [161]. It has been estimated that a global energy system largely based on solar PV could enable net-negative $\mathrm{CO}_{2}$ emissions on the scale of about $30 \mathrm{Gt}$ of $\mathrm{CO}_{2}$ per year, enabling rebalancing to about $350 \mathrm{ppm}$ of atmospheric $\mathrm{CO}_{2}$, which is regarded as a more sustainable $\mathrm{CO}_{2}$ level [162]; this would require about $10 \%$ of the total installed PV capacity [19], which is deemed energetically affordable.

Section 3.1.10, "Hidden Fossil Fuel Subsidy" is written under the underlying assumption that fossil fuel inputs are inherent to renewable energy technology pathways, which is not the case. Clearly, in a world dominated by fossil fuel energy, every process will be dependent upon fossil fuels to some extent, even if indirectly, but that does not mean that the system cannot change. To draw a parallel, in the early days of oil discovery, drilling rigs were transported by horse, but of course that does not mean that fossil fuels were necessarily dependent on animal traction. Unless there is an inherent reason why some specific inputs are dependent on fossil fuels, then the technological system can (and probably will) change. While it is possible that a few specific activities may always be partly dependent on coal, a world in which coal was only used for materials production (which represents a small fraction of its current overall use) would be far preferable to the world of today, in terms of reduced environmental impacts. Be that as it may, recent research has indicated that most, if not all, industrial sectors can be shifted fully to renewable energy [94], which includes the global cement and steel industries [79,92,93].

Section 3.1.12, "The Liquid Fuels Question" claims that "it is highly unlikely that synthetic liquid fuel substitutes for FFs [fossil fuels] can be produced sustainably in any more than small quantities for niche applications". Vast literature has been published in recent years on e-fuels and e-chemicals, such as green Hydrogen [85,86,163], e-Methane [164,165], FischerTropsch fuels [166,167], e-Ammonia [168,169] and e-Methanol [170,171], all showing that electricity-based fuels are in reach. In a global energy system transition analysis reaching $100 \%$ RE in 2050 [46], with $90 \%$ electricity share in primary energy (mainly PV, wind and some hydropower) and strong growth in energy service demands, it has been shown that the total energy system cost can be kept at present levels, while the overall energy 
system efficiency can be increased by a factor of two [46], mainly due to the phase-out of combustion processes which can be substituted by direct electricity-based processes. The segments which cannot be directly electrified can be indirectly electrified with Power-to- $X$ processes and e-fuels, such as for long-distance marine [172] and aviation transportation and high temperature industrial processes. The transport sector can be expanded for more passenger and freight transportation, while the total final energy demand can be kept stable and primary energy demand would grow only moderately, but for three times more transportation, until 2050, since the additional energy demand for e-fuels is counterbalanced by less energy demand for road transportation due to the increased energy conversion efficiency of electric power motors [173]. This documents that stable cost, net-zero $\mathrm{CO}_{2}$ emissions, high energy system efficiency, e-fuels and $100 \%$ renewable energy can be achieved [46] and for higher societal welfare with less air pollution and related health costs; and such a transition would also lead to more jobs than for the present energy system $[32,174]$.

\section{Conclusions}

This rebuttal has exposed the many flaws in the so-called review of renewable energy (RE) presented by Siebert and Rees and in so doing it has cited just a sample of the many peer-reviewed studies which the original "review" paper did not mention. Perhaps the most fundamental flaw of that paper is an unacceptable non-scientific approach that includes selective (and hence biased) screening of the literature focusing on the challenges related to technologically enabled renewable energy solutions, without discussing any of the proposed solutions. Then, such a biased perspective is used to reject the possibility that RE may have a sustainable, rather than simply transitional, role in humanity's future. Instead, Seibert and Rees adopt the fatalistic and unimaginative perspective that the only way to solve the problem is to reject technological renewable energy solutions entirely and adopt an alternative "one-earth sustainability strategy" paradigm whereby just 1 billion people would inhabit the Earth, due to a forced reduction of population and RE would be derived only from wood, biomass, animal energy, and mechanical (not electric) wind energy.

It is unfortunate, counterproductive, and ethically deplorable that the authors turn a legitimate discussion of the challenges of defossilizing the global economy into a political diatribe, castigating the potential for renewables to contribute to the overall solution.

It is therefore absolutely necessary to stress that analyses like Siebert and Rees' present not only a distorted perspective by cherry-picking references and ignoring the mainstream literature in almost every section of the paper; in fact, their analysis is fundamentally flawed in design. It views the energy transition in the abstract, divorcing it from the realities of the world and the energy context in which policy-makers must make decisions. Currently, each year humans use 173,000 TWh of energy, roughly $75 \%$ of which comes from fossil fuels. The pertinent question therefore is not whether renewables are perfect, rather it is whether renewables and the energy transition in general will be better than the existing system. These authors do not acknowledge the obvious counterpoint that our current energy system is wholly unsustainable and unviable even in the short run. Where is the "Problems with Oil" section? It is the contention of these authors, and again the weight of the academic consensus in general, that renewable energy technologies will improve livelihoods compared to a continued fossil fuel-dominated world.

Author Contributions: Conceptualization, V.F.; methodology, V.F., M.R., C.B. and E.L.; formal analysis, V.F., M.R., C.B. and E.L.; investigation and resources, V.F., M.R., C.B., E.L., B.J.S., R.M.S., P.V., A.J.-W., D.L., A.R., S.B., M.C.-D., M.G., D.M., M.J.R.P., P.S. and S.S.; writing-original draft preparation, V.F., M.R. and C.B.; writing-review and editing, V.F., M.R., C.B., D.L., A.J.-W. and E.L.; project administration, V.F. All authors have read and agreed to the published version of the manuscript.

Funding: This research received no external funding.

Informed Consent Statement: Not applicable. 
Data Availability Statement: All cited references are available in the literature.

Conflicts of Interest: The views expressed are purely those of the authors and may not in any circumstances be regarded as stating an official position of the respective institutions with which they are affiliated.

\section{References}

1. Seibert, M.K.; Rees, W.E. Through the Eye of a Needle: An Eco-Heterodox Perspective on the Renewable Energy Transition. Energies 2021, 14, 4508. [CrossRef]

2. Klein, R.J.; Huq, S.; Denton, F.; Downing, T.E.; Richels, R.G.; Robinson, J.B.; Toth, F.L. Inter-relationships between adaptation and mitigation. In Climate Change 2007: Impacts, Adaptation and Vulnerability. Contribution of Working Group II to the Fourth Assessment Report of the Intergovernmental Panel on Climate Change; Parry, M.L., Canziani, O.F., Palutikof, J.P., van der Linden, P.J., Hanson, C.E., Eds.; Cambridge University Press: Cambridge, UK, 2007; pp. 745-777.

3. Vidal, O.; Goffé, B.; Arndt, N. Metals for a Low-Carbon Society. Nat. Geosci. 2013, 6, 894-896. [CrossRef]

4. Hund, K.; LaPorta, D.; Fabregas, T.; Laing, T.; Drexhage, J. Minerals for Climate Action: The Mineral Intensity of the Clean Energy Transition; The World Bank Group, Climate-Smart Mining Initiative: Washington, DC, USA, 2020.

5. Michaux, S.P. The Mining of Minerals and the Limits to Growth; Geological Survey of Finland: Espoo, Finland, 2021.

6. Sovacool, B.K.; Hook, A.; Martiskainen, M.; Brock, A.; Turnheim, B. The Decarbonisation Divide: Contextualizing Landscapes of Low-Carbon Exploitation and Toxicity in Africa. Glob. Environ. Chang. 2020, 60, 102028. [CrossRef]

7. Sovacool, B.K. Who Are the Victims of Low-Carbon Transitions? Towards a Political Ecology of Climate Change Mitigation. Energy Res. Soc. Sci. 2021, 73, 101916. [CrossRef]

8. Chowdhury, M.S.; Rahman, K.S.; Chowdhury, T.; Nuthammachot, N.; Techato, K.; Akhtaruzzaman, M.; Tiong, S.K.; Sopian, K.; Amin, N. An Overview of Solar Photovoltaic Panels' End-of-Life Material Recycling. Energy Strategy Rev. 2020, $27,100431$. [CrossRef]

9. Xu, Y.; Li, J.; Tan, Q.; Peters, A.L.; Yang, C. Global Status of Recycling Waste Solar Panels: A Review. Waste Manag. 2018, 75, 450-458. [CrossRef]

10. Liu, P.; Barlow, C.Y. Wind Turbine Blade Waste in 2050. Waste Manag. 2017, 62, 229-240. [CrossRef]

11. European Commission, Critical Materials for Strategic Technologies and Sectors in the EU-A Foresight Study. 2020. Available online: https://rmis.jrc.ec.europa.eu/uploads/CRMs_for_Strategic_Technologies_and_Sectors_in_the_EU_2020.pdf (accessed on 4 November 2021).

12. U.S. Department of Energy. Department of Energy's Strategy to Support Domestic Critical Mineral and Material Supply Chains (FY 2021-2031), Critical Minerals and Materials. Available online: https://www.energy.gov/sites/default/files/2021/01/f82/ DOE\%20Critical\%20Minerals\%20and\%20Materials\%20Strategy_0.pdf (accessed on 4 November 2021).

13. U.S. Geological Survey. Critical Mineral Commodities in Renewable Energy. Available online: https://www.usgs.gov/media/ images/critical-mineral-commodities-renewable-energy (accessed on 4 November 2021).

14. Junne, T.; Wulff, N.; Breyer, C.; Naegler, T. Critical materials in global low-carbon energy scenarios: The case for neodymium, dysprosium, lithium, and cobalt. Energy 2020, 211, 118532. [CrossRef]

15. Greim, P.; Solomon, A.A.; Breyer, C. Assessment of Lithium criticality in the global energy transition and addressing policy gaps in transportation. Nat. Commun. 2020, 11, 4570. [CrossRef] [PubMed]

16. Grelle, T.; Schmülling, C.; Zimmerschied, P. Magnet-free HV traction drives with contactless power transmission. MTZ Worldw. 2021, 4, 28-33. [CrossRef]

17. Gourley, S.W.D.; Or, T.; Chen, Z. Breaking free from cobalt reliance in lithium-ion batteries. iScience 2020, 23, 101505. [CrossRef] [PubMed]

18. Goldschmidt, J.C.; Wagner, L.; Pietzcker, R.; Friedrich, L. Technological learning for resource efficient terawatt scale photovoltaics. Energy Environ. Sci. 2021, in press. [CrossRef]

19. Breyer, C.; Bogdanov, D.; Khalili, S.; Keiner, D. Solar photovoltaics in 100\% renewable energy systems. In Encyclopedia of Sustainability Science and Technology; Meyers, R.A., Ed.; Springer: New York, NY, USA, 2021. [CrossRef]

20. Moats, M.; Alagha, L.; Awuah-Offei, K. Towards resilient and sustainable supply of critical elements from the copper supply chain: A review. J. Clean. Prod. 2021, 307, 127207. [CrossRef]

21. Redinger, M.; Lokanc, M.; Eggert, R.G.; Woodhouse, M.; Goodrich, A.C. The Present, Mid-Term, and Long-Term Supply Curves for Tellurium; and Updates in the Results from NREL's CdTe PV Module Manufacturing Cost Model, NREL/PR-6A20-60430. 2013. Available online: https:/ / www.nrel.gov / docs / fy13osti/60430.pdf (accessed on 4 November 2021).

22. CIGS-PV. CIGS Thin Film Photovoltaics for EU's Prosperity, Energy Transition and Enabling Net Zero Emission Targets. Available online: https:/ / cigs-pv.net/wortpresse/wp-content/uploads/2021/07/Indium_Availability_for_CIGS_thin-film_solar_cells_ in_Europe.pdf (accessed on 4 November 2021).

23. Paire, M.; Lombez, L.; Donsanti, F.; Jubault, M.; Collin, S.; Pelouard, J.L.; Guillemoles, J.F.; Lincot, D. Cu (In, Ga)Se 2 microcells: High efficiency and low material consumption. J. Renew. Sustain. Energy 2013, 5, 11202. [CrossRef]

24. Fthenakis, V.M.; Wang, W.; Kim, H.C. Life Cycle Inventory Analysis in the Production of Metals used in Photovoltaics. Renew. Sustain. Energy Rev. 2009, 13, 493-517. [CrossRef] 
25. Fthenakis, V.M. Sustainability of photovoltaics: The case for thin-film solar cells. Renew. Sustain. Energy Rev. 2009, 13, 2746-2750. [CrossRef]

26. Fthenakis, V.M. Sustainability metrics for extending thin-film photovoltaics to terawatt levels. MRS Bull. 2012, 37, 425-430. [CrossRef]

27. Matsuno, Y.; Hur, T.; Fthenakis, V. Dynamic Modeling of Cadmium Substance Flow with Zinc and Steel in Japan. Resour. Conserv. Recycl. 2012, 61, 83-90. [CrossRef]

28. Anctil, A.; Fthenakis, V. Critical metals in strategic photovoltaic technologies: Abundance versus recyclability. Prog. Photovolt. Res. Appl. 2013, 21, 1253-1259. [CrossRef]

29. Fthenakis, V.; Anctil, A. Direct Te mining: Resource availability and impact on cumulative energy demand of CdTe PV life-cycles. IEEE J. Photovolt. 2013, 3, 433-438. [CrossRef]

30. Fthenakis, V.; Athias, C.; Blumenthal, A.; Kulur, A.; Magliozzo, J.; Ng, D. Sustainability Evaluation of CdTe PV in Large Scale Penetration. Renew. Sustain. Energy Rev. 2020, 123, 10977. [CrossRef]

31. Victoria, M.; Haegel, N.; Peters, I.M.; Sinton, R.; Jäger-Waldau, A.; Cañizo, C.; Breyer, C.; Stocks, M.; Blakers, A.; Kaizuka, I.; et al. Solar photovoltaics is ready to power a sustainable future. Joule 2021, 5, 1041-1056. [CrossRef]

32. Jacobson, M.Z.; Delucchi, M.A.; Cameron, M.A.; Coughlin, S.J.; Hay, C.A.; Manogaran, I.P.; Shu, Y.; Krauland, A.K. Impacts of Green new deal energy plans on grid stability, costs, jobs, health, and climate in 143 countries. One Earth 2019, 1, 449-463. [CrossRef]

33. Haegel, N.M.; Atwater, H., Jr.; Barnes, T.; Breyer, C.; Burrell, A.; Chiang, Y.-M.; DeWolf, S.; Dimmler, B.; Feldman, D.; Glunz, S.; et al. Terawatt-scale photovoltaics: Transform global energy. Science 2019, 364, 836-838. [CrossRef] [PubMed]

34. Pursiheimo, E.; Holttinen, H.; Koljonen, T. Intersectoral effects of high renewable energy share in global energy system. Renew. Energy 2019, 136, 1119-1129. [CrossRef]

35. Verlinden, P.J. Future challenges for photovoltaic manufacturing at the terawatt level. J. Renew. Sustain. Energy 2020, $12,53505$. [CrossRef]

36. Haas, J.; Moreno-Leiva, S.; Junne, T.; Chen, P.-J.; Pamparana, G.; Nowak, W.; Kracht, W.; Ortiz, J.M. Copper mining: 100\% solar electricity by 2030? Appl. Energy 2020, 262, 114506. [CrossRef]

37. Mills, M.P. The New Energy Economy: An Exercise in Magical Thinking; The Manhattan Institute: New York, NY, USA, 2019. Available online: https:/ / www.peabodyenergy.com/Peabody/media/MediaLibrary/Case\%20for\%20Coal/Magical-Thinking-Mills-\%2 8March-2019\%29.pdf (accessed on 10 November 2021).

38. Zehner, O. Green Illusions: The Dirty Secrets of Clean Energy and the Future of Environmentalism; Our sustainable future; University of Nebraska Press: Lincoln, NE, USA, 2012; ISBN 97808-03237759.

39. Solar Energy Technology Office (SETO). Energy Efficiency and Renewable Energy (EERE) U.S. Department of Energy, SunShot Vision Study. 2012. Available online: https:/ /www.energy.gov/eere/solar/sunshot-vision-study (accessed on 4 November 2021)

40. Solar Energy Technology Office (SETO). Energy Efficiency and Renewable Energy (EERE) U.S. Department of Energy, On the Path to Sunshot. 2016. Available online: https:/ / www.energy.gov/eere/solar/path-sunshot (accessed on 4 November 2021).

41. Solar Futures Study, Office of Energy Efficiency and Renewable Energy (EERE) U.S. Department of Energy. 2021. Available online: https:/ / www.energy.gov/sites/default/files/2021-09/Solar\%20Futures\%20Study.pdf (accessed on 4 November 2021).

42. Zweibel, K.; Mason, J.; Fthenakis, V. A Solar Grand Plan. Sci. Am. 2008, 298, 64-73. Available online: https://www. scientificamerican.com/article/a-solar-grand-plan/ (accessed on 4 November 2021). [CrossRef]

43. Fthenakis, V.; Mason, J.; Zweibel, K. The Technical, Geographical and Economic Feasibility for Solar Energy to Supply the Energy Needs of the United States. Energy Policy 2009, 37, 387-399. [CrossRef]

44. Larson, E.; Greig, C.; Jenkins, J.; Mayfield, E.; Pascale, A.; Zhang, C.; Drossman, J.; Williams, R.; Pacala, S.; Socolow, R.; et al. Net-Zero America: Potential Pathways, Infrastructure, and Impacts; Interim Report; Princeton University: Princeton, NJ, USA, 2020.

45. Ives, M.C.; Righetti, L.; Schiele, J.; De Meyer, K.; Hubble-Rose, L.; Teng, F.; Kruitwagen, L.; Tillmann-Morris, L.; Wang, T.; Way, R.; et al. A New Perspective on Decarbonising the Global Energy System. Oxford: Smith School of Enterprise and the Environment; University of Oxford: Oxford, UK, 2021.

46. Bogdanov, D.; Ram, M.; Aghahosseini, A.; Gulagi, A.; Oyewo, A.S.; Child, M.; Caldera, U.; Sadovskaia, K.; Farfan, J.; Barbosa, L.D.S.N.S.; et al. Low-cost renewable electricity as the key driver of the global energy transition towards sustainability. Energy 2021, 227, 120467. [CrossRef]

47. Aghahosseini, A.; Bogdanov, D.; Breyer, C. A Techno-Economic Study of an Entirely Renewable Energy-Based Power Supply for North America for 2030 Conditions. Energies 2017, 10, 1171. [CrossRef]

48. Aghahosseini, A.; Bogdanov, D.; Barbosa, L.S.N.S.; Breyer, C. Analysing the feasibility of powering the Americas with renewable energy and inter-regional grid interconnections by 2030. Renew. Sustain. Energy Rev. 2019, 105, 187-205. [CrossRef]

49. University of California Berkeley, Goldman School of Public Policy. The 2035 Report: Plummeting Solar, Wind, And Battery Costs Can Accelerate Our Clean Electricity Future. 2020. Available online: http://www.2035report.com/wp-content/uploads/2020 /06/2035-Report.pdf?hsCtaTracking=8a85e9ea-4ed3-4ec0-b4c6-906934306ddb\%7Cc68c2ac2-1db0-4d1c-82a1-65ef4daaf6c1 (accessed on 26 May 2021). 
50. Wesoff, E. The US Added 13.3 GW of Solar in 2019, Beating New Wind and Gas Capacity. PV Magazine, 18 March 2020. Available online: https:/ / www.pv-magazine.com/2020/03/18/the-us-added-13-3-gw-of-solar-in-2019-beating-wind-and-gas-in-

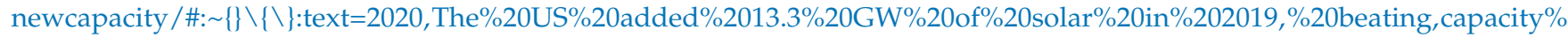
20now $\% 20$ tops $\% 2076 \% 20 \mathrm{GW}$ (accessed on 26 May 2021).

51. Clack, C.T.M.; Qvist, S.A.; Apt, J.; Bazilian, M.; Brandt, A.R.; Caldeira, K.; Davis, S.J.; Diakov, V.; Handschy, M.A.; Hines, P.D.H.; et al. Evaluation of a Proposal for Reliable Low-Cost Grid Power with 100\%Wind, Water, and Solar. Proc. Natl. Acad. Sci. USA 2017, 114, 6722-6727. [CrossRef] [PubMed]

52. Jacobson, M.Z.; Delucchi, M.A.; Cameron, M.A.; Frew, B.A. The United States can keep the grid stable at low cost with $100 \%$ clean, renewable energy in all sectors despite inaccurate claims. Proc. Natl. Acad. Sci. USA 2017, 14, E5021-E5023. [CrossRef]

53. Consolidation of Peer-Review Papers from 18 Independent Groups on 100\% RE in Different Parts of the World. Available online: https:/ / web.stanford.edu/group/efmh/jacobson/Articles/I/CombiningRenew/100PercentPaperAbstracts.pdf (accessed on 30 October 2021).

54. Hansen, K.; Breyer, C.; Lund, H. Status and Perspectives on 100\% Renewable Energy Systems. Energy 2019, 175, 471-480. [CrossRef]

55. Diesendorf, M.; Elliston, B. The feasibility of $100 \%$ renewable electricity systems: A response to critics. Renew. Sustain. Energy Rev. 2018, 93, 318-330. [CrossRef]

56. Brown, T.W.; Bischof-Niemz, T.; Blok, K.; Breyer, C.; Lundn, H.; Mathiesen, B.V. Response to 'Burden of proof: A comprehensive review of the feasibility of 100\% renewable-electricity systems'. Renew. Sustain. Energy Rev. 2018, 92, 834-847. [CrossRef]

57. Fthenakis, V.M.; Lynn, P.A. Electricity from Sunlight: Photovoltaics Systems Integration and Sustainability, 2nd ed.; Wiley: Hoboken, NJ, USA, 2018; ISBN 97811-18963807.

58. Fthenakis, V.; Leccisi, E. Updated sustainability status of crystalline silicon-based photovoltaic systems: Life-cycle energy and environmental impact reduction trends. Prog. Photovolt. Res. Appl. 2021, 1068-1077. [CrossRef]

59. Raugei, M.; Sgouridis, S.; Murphy, D.; Fthenakis, V.; Frischknecht, R.; Breyer, C.; Bardi, U.; Barnhart, C.; Buckley, A.; Carbajales-Dale, M.; et al. Energy Return on Energy Invested (ERoEI) for photovoltaic solar systems in regions of moderate insolation: A comprehensive response. Energy Policy 2017, 102, 377-384. [CrossRef]

60. Raugei, M.; Carbajales-Dale, M.; Barnhart, C.; Fthenakis, V. On energy intensities, energy returned on investment, and energy payback times of electricity generating power plants- Making clear of quite some confusion. Energy 2015, 82, 1088-1091. [CrossRef]

61. Carbajales-Dale, M.; Raugei, M.; Fthenakis, V.; Barnhart, C. Energy return on investment (EROI) of solar PV: An attempt at reconciliation. Proc. IEEE 2015, 103, 995-999. [CrossRef]

62. White, G.; Kramer, J. The Changing Meaning of Energy Return on Investment and the Implications for the Prospects of Post-fossil Civilization. One Earth 2019, 1, 416-422. [CrossRef]

63. Leccisi, E.; Raugei, M.; Fthenakis, V. The energy and environmental performance of ground-mounted photovoltaic systems-A timely update. Energies 2016, 9, 622. [CrossRef]

64. Leccisi, E.; Fthenakis, V. Life-cycle energy demand and carbon emissions of scalable single-junction and tandem perovskite PV. Prog. Photovolt. 2021, 29, 1078-1092. [CrossRef]

65. Raugei, M.; Peluso, A.; Leccisi, E.; Fthenakis, V. Life-cycle carbon emissions and energy return on investment for $80 \%$ domestic renewable electricity with battery storage in California (USA). Energies 2020, 13, 3934. [CrossRef]

66. Raugei, M.; Leccisi, E.; Azzopardi, B.; Jones, C.; Gilber, P.; Zhang, L.; Zhou, Y.; Mander, S.; Mancarella, P. A multi-disciplinary analysis of UK grid mix scenarios with large-scale PV deployment. Energy Policy 2018, 114, 51-62. [CrossRef]

67. Raugei, M.; Leccisi, E.; Fthenakis, V.; Moragas, R.E.; Simsek, Y. Net energy analysis and life cycle energy assessment of electricity supply in Chile: Present status and future scenarios. Energy 2018, 162, 659-668. [CrossRef]

68. Leccisi, E.; Raugei, M.; Fthenakis, V. The energy performance of potential scenarios with large-scale PV deployment in Chile-A dynamic analysis. In Proceedings of the 2018 IEEE 7th WCPEC, a Joint Conference of 45th IEEE PVSC, 28th PVSEC \& 34th EU PVSEC, Waikoloa, HI, USA, 10-15 June 2018; pp. 2441-2446.

69. Raugei, M.; Leccisi, E.; Fthenakis, V. What are the energy and environmental impacts of adding battery storage to photovoltaics? A generalized life cycle assessment. Energy Technol. 2020, 8, 1901146. [CrossRef]

70. Raugei, M. Net Energy Analysis must not compare apples and oranges. Nat. Energy 2019, 4, 86-88. [CrossRef]

71. Fthenakis, V.M.; Kim, H.C. Photovoltaics: Life-cycle analyses. Solar Energy 2011, 85, 1609-1628. [CrossRef]

72. Frischknecht, R.; Stolz, P.; Krebs, L.; de Wild-Scholten, M.; Sinha, P.; Fthenakis, V.; Kim, H.C.; Raugei, M.; Stucki, M. Life Cycle Inventories and Life Cycle Assessment of Photovoltaic Systems; PVPS Task 12, Report T12-19; International Energy Agency (IEA): Upton, NY, USA, 2020.

73. Fthenakis, V.; Frischknecht, R.; Raugei, M.; Kim, H.C.; Alsema, M.; Held, M.; de Wild-Scholten, M. Methodology Guidelines on Life Cycle Assessment of Photovoltaic Electricity, 2nd ed.; PVPS Task 12, Report IEA-PVPS T12-03; International Energy Agency: Upton, NY, USA, 2011.

74. Frischknecht, R.; Itten, R.; Sinha, P.; de Wild-Scholten, M.; Zhang, J.; Fthenakis, V.; Kim, H.C.; Raugei, M.; Stucki, M. Life Cycle Inventories and Life Cycle Assessments of Photovoltaic Systems; PVPS Task 12, Report T12-04; International Energy Agency: Upton, NY, USA, 2015.

75. Dale, M.; Benson, S.M. Energy balance of the global photovoltaic (PV) industry-is the PV industry a net electricity producer? Environ. Sci. Technol. 2013, 47, 3482-3489. [CrossRef] 
76. Friedemann, A.J.; Zhiyuan, F.; Tang, K. Low-Carbon Heat Solutions for Heavy Industry: Sources, Options, and Costs Today; Columbia Center on Global Energy Policy: New York, NY, USA, 2019.

77. Sandalow, D.; Friedmann, J.; Aines, R.; McCormick, C.; McCoy, S.; Stolaroff, J. ICEF Industrial Heat Decarbonization Roadmap; Innovation for Cool Earth Forum: Tokyo, Japan, 2019. Available online: https://www.icef-forum.org/pdf/2019/roadmap/ICEF_ Roadmap_201912.pdf (accessed on 26 May 2021).

78. Friedemann, A.J. When Trucks Stop Running; SpringerBriefs in Energy; Springer International Publishing: Cham, Switzerland, 2016; ISBN 97833-19263731.

79. Bailera, M.; Lisbona, P.; Peña, B.; Romeo, L.M. A review on $\mathrm{CO}_{2}$ mitigation in the Iron and Steel industry through Power to X processes. J. CO2 Util. 2021, 46, 101456. [CrossRef]

80. Kätelhön, A.; Meys, R.; Deutz, S.; Suh, S.; Bardow, A. Climate change mitigation potential of carbon capture and utilization in the chemical industry. Proc. Natl. Acad. Sci. USA 2019, 116, 11187-11194. [CrossRef] [PubMed]

81. Galán-Martin, A.; Tulus, V.; Diaz, I.; Pozo, C.; Pérez-Ramirez, J.; Guillén-Gosálbez, G. Sustainability footprints of a renewable carbon transition for the petrochemical sector within planetary boundaries. One Earth 2021, 4, 565-583. [CrossRef]

82. Turiel, A. Hydrogen Fever 2.0 (I). The Oil Crash, 17 November 2020. Available online: https://crashoil.blogspot.com/2020/11/ la-fiebre-del-hidrogeno-20-i.html (accessed on 30 June 2021).

83. Ginsberg, M.; Atia, A.A.; Venkatraman, M.; Zhang, Z.; Esposito, D.; Fthenakis, V. Integrating solar energy, desalination and electrolysis. Solar RRL, 2021, in press. [CrossRef]

84. International Renewable Energy Agency (IRENA). Innovation landscape brief: Renewable Power-to-Hydrogen, 2019, Abu Dhabi. Available online: https:/ /www.irena.org/-/media/Files/IRENA/Agency/Publication/2019/Sep/IRENA_Power-to-Hydrogen_ Innovation_2019.pdf (accessed on 9 September 2021).

85. Fasihi, M.; Breyer, C. Baseload electricity and Hydrogen supply based on hybrid PV-Wind power plants. J. Clean. Prod. 2020, 243, 118466. [CrossRef]

86. Vartiainen, E.; Breyer, C.; Moser, D.; Medina, E.R.; Busto, C.; Masson, G.; Bosch, E.; Jäger-Waldau, A. True Cost of Solar Hydrogen. Solar RRL 2021, in press. [CrossRef]

87. Koleva, M.; Guerra, O.J.; Eichman, J.; Hodge, B.-M.; Kurtz, J. Optimal design of solar-driven electrolytic hydrogen production systems within electricity markets. J. Power Sources 2021, 483, 229183. [CrossRef]

88. FERC Order No. 2222: Fact Sheet. Available online: https://www.ferc.gov/media/ferc-order-no-2222-fact-sheet (accessed on 9 September 2021).

89. Eichman, J.; Harrison, K.; Peters, M. Novel Electrolyzer Applications: Providing More than Just Hydrogen. In Novel Electrolyzer Applications: Providing More Than Just Hydrogen; Office of Scientific and Technical Information (OSTI): Washington DC, USA, 2014

90. Guerra, O.; Eichman, J.; Kurtz, J.; Hodge, B. Cost Competitiveness of Electrolytic Hydrogen. Joule 2019, 3, 2425-2443. [CrossRef]

91. International Energy Agency (IEA). World Energy Outlook; International Energy Agency: Paris, France, 2020. Available online: https:/ / www.iea.org/reports/world-energy-outlook-2020 (accessed on 9 September 2021).

92. Farfan, J.; Fasihi, M.; Breyer, C. Trends in the global cement industry and opportunities for a long-term sustainable CCU potential for Power-to-X. J. Clean. Prod. 2019, 217, 821-835. [CrossRef]

93. Otto, A.; Robinius, M.; Grube, T.; Schiebahn, S.; Praktiknjo, A.; Stolten, D. Power-to-Steel: Reducing $\mathrm{CO}_{2}$ through the Integration of Renewable Energy and Hydrogen into the German Steel Industry. Energies 2017, 10, 451. [CrossRef]

94. Bogdanov, D.; Gulagi, A.; Fasihi, M.; Breyer, C. Full energy sector transition towards 100\% renewable energy supply: Integrating power, heat, transport and industry sectors including desalination. Appl. Energy 2021, 283, 116273. [CrossRef]

95. Carbajales-Dale, M.; Barnhart, C.; Benson, S.M. Can we afford storage? A dynamic net energy analysis of renewable electricity generation supported by energy storage. Energy Environ. Sci. 2014, 7, 1538-1544. [CrossRef]

96. Görig, M.; Breyer, C. Energy learning curves of PV systems. Environ. Prog. Sustain. Energy 2016, 35, 914-923. [CrossRef]

97. Mulvaney, D. Solar Energy Isn't Always as Green as You Think. IEEE Spectrum. 2014. Available online: https://spectrum.ieee. org/green-tech/solar/solar-energy-isnt-always-as-green-as-you-think (accessed on 26 May 2021).

98. Fthenakis, V.; Moskowitz, P.D.; Lee, J.C. Manufacture of Amorphous Silicon and Gallium Arsenide Thin-Film Solar Cells: An Identification of Potential Health and Safety Hazards. Solar Cells 1984, 13, 43-58. [CrossRef]

99. Moskowitz, P.D.; Fthenakis, V.; Hamilton, L.D.; Lee, J.C. Public health Issues in Photovoltaic Energy Systems: An Overview of Concerns. Solar Cells 1986, 19, 287-299. [CrossRef]

100. Fthenakis, V.; Moskowitz, P.D. Characterization and Controls of Phosphine Hazards in Photovoltaic Cell Manufacture. Solar Cells 1987, 22, 303-317. [CrossRef]

101. Fthenakis, V.M.; Moskowitz, P.D.; Hamilton, L.D. Personal Safety in Thin-Film Photovoltaic Cell Industries. Solar Cells 1987, 19, 269-281. [CrossRef]

102. Fthenakis, V.; Moskowitz, P.D.; Sproull, R.D. Control of Accidental Releases of Hydrogen Selenide and Hydrogen Sulfide in the Manufacture of Photovoltaic Cells: A Feasibility Study. J. Loss Prev. 1988, 1, 206-212. [CrossRef]

103. Fthenakis, V.; Moskowitz, P.D. Health and Safety Aspects of Thin-Film Photovoltaic Cell Manufacturing Technologies. Plant/Oper. Prog. 1988, 7, 236-241. [CrossRef]

104. Fthenakis, V.; Moskowitz, P.D. A Checklist of Suggested Safe Practices for the Storage, Distribution, Use and Disposal of Toxic and Hazardous Gases in Photovoltaic Cell Production. Solar Cells 1991, 31, 513-525. 
105. Fthenakis, V.; Moskowitz, P.D. Thin-Film Photovoltaic Cells: Health and environmental Issues in their Manufacture, Use and Disposal. Prog. Photovolt. Res. Appl. 1995, 3, 295-306. [CrossRef]

106. Fthenakis, V. Prevention and Control of Accidental Releases of Hazardous Materials in PV Facilities. Prog. Photovolt. Res. Appl. 1998, 6, 91-98. [CrossRef]

107. Ciccarelli, G.; Fthenakis, V.; Boccio, J. A Simple Method of Analysis for Gas Explosions. J. Loss Prev. 1999, 12, 157-165. [CrossRef]

108. Fthenakis, V.; Morris, S.C.; Moskowitz, P.D.; Morgan, D. Toxicity of CdTe, CIS and CGS. Prog. Photovolt. Res. Appl. 1999, 7, 489-497. [CrossRef]

109. Fthenakis, V.; Moskowitz, P.D. Photovoltaics: Environmental, Safety and Health Issues and Perspectives. Prog. Photovolt. Res. Appl. 2000, 8, 27-38. [CrossRef]

110. Fthenakis, V. Life Cycle Impact Analysis of Cadmium in CdTe Photovoltaic Production. Renew. Sustain. Energy Rev. 2004, 8, 303-334. [CrossRef]

111. Fthenakis, V. Multilayer Protection Analysis for Photovoltaic Manufacturing Facilities. AIChE Process. Saf. Prog. 2001, 20, 87-94. [CrossRef]

112. Fthenakis, V.; Bulawka, A.O. Photovoltaics, Environmental Impact of. In Encyclopedia of Energy; Elsevier: Amsterdam, The Netherlands, 2004; Volume 5, pp. 61-69, ISBN 97801-21764807.

113. Fthenakis, V.; Kim, H.C. Greenhouse gas Emissions from Solar Electric and Nuclear Power: A Life Cycle Study. Energy Policy 2007, 35, 2549-2557. [CrossRef]

114. Fthenakis, V.; Kim, H.C. CdTe Photovoltaics: Life-cycle environmental profile and comparisons. Thin Solid Films. 2007, 515, 5961-5963. [CrossRef]

115. Fthenakis, V.M.; Eberspacher, C.; Moskowitz, P.D. Recycling Strategies to Enhance the Viability of CIS Photovoltaics, Progress in Photovoltaics. Res. Appl. 1996, 4, 447-456.

116. Fthenakis, V. End-of Life Management and Recycling of PV Modules. Energy Policy 2000, 28, 1051-1058. [CrossRef]

117. Choi, J.K.; Fthenakis, V.M. Economic Feasibility of Photovoltaic Module Recycling: Survey and Model. J. Ind. Ecol. 2010, 14, 947-964. [CrossRef]

118. Choi, J.K.; Fthenakis, V.M. Design and Optimization of Photovoltaics Recycling Infrastructure. Environ. Sci. Technol. 2010, 44, 8678-8683. [CrossRef] [PubMed]

119. Fthenakis, V. Considering the total cost of electricity from sunlight and the alternatives. Proc. IEEE 2015, 103, 283-286. [CrossRef]

120. Corcelli, F.; Ripa, M.; Leccisi, E.; Cigolotti, V.; Fiandra, V.; Graditi, G.; Sannino, L.; Tammaro, M.; Ulgiati, S. Sustainable urban electricity supply chain-Indicators of material recovery and energy savings from crystalline silicon photovoltaic panels end-of-life. Ecol. Indic. 2018, 94, 37-51. [CrossRef]

121. Barnwal, A.; Dhawan, N. Recycling of discarded mobile printed circuit boards for extraction of gold and copper. Sustain. Mater. Technol. 2020, 25, e00164. [CrossRef]

122. Bartie, N.J.; Abadías Llamas, A.; Heibeck, M.; Fröhling, M.; Volkova, O.; Reuter, M.A. The simulation-based analysis of the resource efficiency of the circular economy-The enabling role of metallurgical infrastructure. Miner. Process. Extr. Metall. 2020 129, 229-249. [CrossRef]

123. Bookhagen, B.; Bastian, D.; Buchholz, P.; Faulstich, M.; Opper, C.; Irrgeher, J.; Prohaska, T.; Koeberl, C. Metallic resources in smartphones. Resour. Policy 2020, 68, 101750. [CrossRef]

124. Bourgeois, D.; Lacanau, V.; Mastretta, R.; Contino-Pepin, C.; Meyer, D. A simple process for the recovery of palladium from wastes of printed circuit boards. Hydrometallurgy 2020, 191, 105241. [CrossRef]

125. Carrara, S.; Alves Dias, P.; Plazzotta, B.; Pavel, C. Raw Materials Demand for Wind and Solar PV Technologies in the Transition Towards a Decarbonised Energy System; EUR 30095 EN; Publication Office of the European Union: Luxembourg, 2020; ISBN 97892-76162254. Available online: https:/ / core.ac.uk/download/pdf/322747915.pdf (accessed on 8 November 2021).

126. Sciubba, E. Extended exergy accounting applied to energy recovery from waste: The concept of total recycling. Energy 2003, 28, 1315-1334. [CrossRef]

127. Fthenakis, V.; Kim, H.C.; Alsema, E. Emissions from photovoltaic life cycles. Environ. Sci. Technol. 2008, 42, 2168-2174. [CrossRef]

128. European Commission (EC). Directive 2012/19/EU of the European Parliamentand of the Council of 4 July 2012 on Waste Electrical and Electronic Equipment; European Commission: Brussels, Belgium, 2012.

129. European Commission (EC). Mandate to the European Standardisation Organizations for Standardisation in the Field of Waste Electrical and Electronic Equipment; Directive 2012/19/EU (WEEE); European Commission: Brussels, Belgium, 2013.

130. Sinha, P.; Raju, S.; Drozdiak, K.; Wade, A. Life cycle management and recycling of PV systems. PV-Tech Power 2017, 13, 47-50.

131. Burrows, K.; Fthenakis, V. Glass Needs in a Growing PV Industry. Sol. Mater. Sol. Cells 2015, 132, 455-459. [CrossRef]

132. De Castro, C.; Capellán-Pérez, I. Standard, Point of Use, and Extended Energy Return on Energy Invested (EROI) from Comprehensive Material Requirements of Present Global Wind, Solar, and Hydro Power Technologies. Energies 2020, 13, 3036. [CrossRef]

133. Capellán-Pérez, I.; de Castro, C.; Miguel González, L.J. Dynamic Energy Return on Energy Investment (EROI) and Material Requirements in Scenarios of Global Transition to Renewable Energies. Energy Strategy Rev. 2019, 26, 100399. [CrossRef]

134. Ferroni, F.; Guekos, A.; Hopkirk, R.J. Further Considerations to: Energy Return on Energy Invested (ERoEI) for Photovoltaic Solar Systems in Regions of Moderate Insolation. Energy Policy 2017, 107, 498-505. [CrossRef] 
135. Prieto, P.A.; Hall, C.A.S. Spain's Photovoltaic Revolution: The Energy Return on Investment; SpringerBriefs in Energy; Energy Analysis; Springer: New York, NY, USA, 2013; ISBN 97814-41994363.

136. IRENA. Electricity Storage and Renewables: Costs and Markets to 2030; International Renewable Energy Agency: Abu Dhabi, United Arab Emirates, 2017. Available online: https:/ /www.irena.org/publications/2017/oct/electricity-storage-and-renewables-costsand-markets (accessed on 10 September 2021).

137. Nikolakakis, T.; Fthenakis, V. The Optimum Mix of Electricity from Wind- and Solar-Sources in Conventional Power Systems: Evaluating the Case for New York State. Energy Policy 2011, 39, 6972-6980. [CrossRef]

138. Perez, M.; Perez, R.; Rábago, K.R.; Putnam, M. Overbuilding \& curtailment: The cost-effective enablers of firm PV generation. Solar Energy 2019, 180, 412-422.

139. Perez, R.; Perez, M. A fundamental look at supply side energy reserves for the planet. IEA SHC 2009, 50, 2. Available online: https: / / citeseerx.ist.psu.edu/viewdoc/download?doi=10.1.1.498.8623\&rep=rep1\&type=pdf (accessed on 8 November 2021).

140. Gevogian, V.; Burra, R.; Morjaria, M. Hybrid Utility-Scale PV-Wind Storage Plants for Dispatchability and Reliability Services. In Proceedings of the 3rd International Hybrid Power Systems Workshop; Tenerife, Spain, 8-9 May 2018. Available online: https: // www.nrel.gov/docs/fy18osti/71551.pdf (accessed on 1 November 2021).

141. Raugei, M.; Peluso, A.; Leccisi, E.; Fthenakis, V. Life-Cycle Carbon Emissions and Energy Implications of High Penetration of Photovoltaics and Electric Vehicles in California. Energies 2021, 14, 5165. [CrossRef]

142. Volkswagen. 2021. Available online: https://www.volkswagenag.com/en/news/2021/03/traton-group-boosts-investmentin-electric-mobility.html (accessed on 9 September 2021).

143. Auto Motor und Sport. 2021. Available online: https://www.auto-motor-und-sport.de/tech-zukunft/alternative-antriebe/ interview-mit-traton-chef-stratege-andreas-kammel/ (accessed on 9 September 2021).

144. Renault Trucks. 2021. Available online: https://www.renault-trucks.com/en/transport-solutions/electromobility (accessed on 9 September 2021).

145. Daimler Trucks. 2021. Available online: https://media.daimler.com/marsMediaSite/en/instance/ko/Daimler-Truck-AG-andCATL-expand-global-partnership-joint-development-of-sophisticated-truck-focused-batteries-and-supply-agreed-beyond-20 30.xhtml?oid=50009915 (accessed on 9 September 2021).

146. BYD Trucks. 2021. Available online: https://insideevs.com/news/532462/byd-next-generation-electric-trucks / (accessed on 9 September 2021).

147. Samsung SDI, Energy Storage System Battery Business-Batteries by Samsung SDI, Yongin, Korea. 2018. Available online: https://www.samsungsdi.com/upload/ess_brochure/201902_Samsung\%20SDI\%20ESS_EN.pdf (accessed on 1 November 2021).

148. Peters, I.M.; Breyer, C.; Jaffer, S.; Kurtz, S.; Reindl, T.; Sinton, R.; Vetter, M. The Role of Batteries in Meeting the PV Terawatt Challenge. Joule 2021, 5, 1353-1370. [CrossRef]

149. Rajaeifar, M.A.; Raugei, M.; Steubing, B.; Hartwell, A.; Anderson, P.; Heidrich, O. Life Cycle Assessment of lithium-ion battery recycling using pyrometallurgical technologies. J. Ind. Ecol. 2021, 25, 1560-1571. [CrossRef]

150. Dai, Q.; Winjobi, O. Updates for Battery Recycling and Materials in GREET®2019. Energy Systems Division. Argonne National Laboratory. Available online: https://greet.es.anl.gov/publication-battery_recycling_materials_2019 (accessed on 28 April 2021).

151. Arambarri, J.; Hayden, J.; Elkurdy, M.; Meyers, B.; Hamatteh, Z.S.A.; Abbassi, B.; Omar, W. Lithium ion car batteries: Present analysis and future predictions. Environ. Eng. Res. 2019, 24, 699-710. [CrossRef]

152. Lenzen, M.; Jesper, M. Energy and $\mathrm{CO}_{2}$ life-cycle analyses of wind turbines-Review and applications. Renew. Energy 2002, 26, 339-362. [CrossRef]

153. Kubiszewski, I.; Cleveland, C.J.; Endres, P.K. Meta-analysis of net energy return for wind power systems. Renew. Energy 2010, 35, 218-225. [CrossRef]

154. Dale, M. A comparative analysis of energy costs of photovoltaic, solar thermal, and wind electricity generation technologies. Appl. Sci. 2013, 3, 325-337.

155. Dolan, S.L.; Heath, G.A. Life cycle greenhouse gas emissions of utility-scale wind power: Systematic review and harmonization. J. Ind. Ecol. 2012, 16, S136-S154. [CrossRef]

156. National Renewable Energy Laboratory (NREL). Life Cycle Assessment Harmonization. 2021. Available online: https://www. nrel.gov/analysis/life-cycle-assessment.html (accessed on 9 September 2021).

157. Service, F. Cost Plunges for Capturing Carbon Dioxide from the Air. Science. 2018. Available online: https://www.sciencemag. org/news/2018/06/cost-plunges-capturing-carbon-dioxide-air (accessed on 1 November 2021).

158. Fasihi, M.; Efimova, O.; Breyer, C. Techno-economic assessment of $\mathrm{CO}_{2}$ direct air capture plants. J. Clean. Prod. 2019, 224, 957-980. [CrossRef]

159. Breyer, C.; Fasihi, M.; Aghahosseini, A. Carbon Dioxide Direct Air Capture for effective Climate Change Mitigation based on Renewable Electricity: A new Type of Energy System Sector Coupling. Mitig. Adapt. Strateg. Glob. Chang. 2020, $25,43-65$. [CrossRef]

160. Breyer, C.; Fasihi, M.; Bajamundi, C.; Creutzig, F. Direct Air Capture of $\mathrm{CO}_{2}-\mathrm{A}$ key technology for ambitious climate change mitigation. Joule 2019, 3, 2053-2057. [CrossRef]

161. Creutzig, F.; Breyer, C.; Hilaire, J.; Minx, J.; Peters, G.; Socolow, R. The mutual dependence of negative emission technologies and energy systems. Energy Environ. Sci. 2019, 12, 1805-1817. [CrossRef] 
162. Hansen, J.; Sato, M.; Kharecha, P.; von Schmuckmann, K.; Beerling, D.J.; Cao, J.; Marcott, S.; Masson-Delmotte, V.; Prather, M.J.; Rohling, E.J.; et al. Young people's burden: Requirement of negative $\mathrm{CO}_{2}$ emissions. Earth Syst. Dyn. 2017, 8, 577-616. [CrossRef]

163. Brändle, G.; Schönfisch, M.; Schulte, S. Estimating long-erm global supply costs for low-carbon Hydrogen. Appl. Energy 2021, 302, 117481. [CrossRef]

164. Sterner, M. Bioenergy and Renewable Power Methane in Integrated 100\% Renewable Energy Systems. 2009. Available online: http: / / publica.fraunhofer.de/documents/N-139644.html (accessed on 20 September 2021).

165. Blanco, H.; Nijs, W.; Ruf, J.; Faaij, A. Potential of Power-to-Methane in the EU energy transition to a low carbon system using cost optimization. Appl. Energy 2018, 232, 323-340. [CrossRef]

166. Drünert, S.; Neuling, U.; Zitscher, T.; Kaltschmitt, M. Power-to-Liquid fuels for aviation-Processes, resources and supply potential under German conditions. Appl. Energy 2020, 277, 115578. [CrossRef]

167. Fasihi, M.; Bogdanov, D.; Breyer, C. Techno-Economic Assessment of Power-to-Liquids (PtL) Fuels Production and Global Trading Based on Hybrid PV-Wind Power Plants. Energy Proc. 2016, 99, 243-268. [CrossRef]

168. Fasihi, M.; Weiss, R.; Savolainen, J.; Breyer, C. Global potential of green ammonia based on hybrid PV-wind power plants. Appl. Energy 2021, 294, 116170. [CrossRef]

169. Osman, O.; Sgouridis, S.; Sleptchenko, A. Scaling the production of renewable ammonia-A techno-economic optimization applied in regions with high insolation. J. Clean. Prod. 2020, 271, 121627. [CrossRef]

170. Lonis, R.; Tola, V.; Cau, G. Assessment of integrated energy systems for the production and use of renewable methanol by water electrolysis and $\mathrm{CO}_{2}$ Hydrogenation. Fuel 2021, 285, 119160. [CrossRef]

171. Fasihi, M.; Breyer, C. Synthetic Methanol and Dimethyl Ether Production based on Hybrid PV-Wind Power Plants. In Proceedings of the 11th International Renewable Energy Storage Conference (IRES 2017), Düsseldorf, Germany, 14-16 March 2017; LUT Research Portal Converis_LUT University: Lappeenranta, Finland, 2017. Available online: https://research.lut.fi/converis/ portal/Publication/10574933?auxfun\%C2\%BC\&lang\%C2\%BCen_GB (accessed on 1 November 2021).

172. Horvath, S.; Fasihi, M.; Breyer, C. Techno-Economic Analysis of a Decarbonized Shipping Sector: Technology Suggestions for a Fleet in 2030 and 2040. Energy Convers. Manag. 2018, 164, 230-241. [CrossRef]

173. Khalili, S.; Rantanen, E.; Bogdanov, D.; Breyer, C. Global Transportation Demand Development with Impacts on the Energy Demand and Greenhouse Gas Emissions in a Climate-Constrained World. Energies 2019, 12, 3870. [CrossRef]

174. Ram, M.; Osorio-Aravena, J.C.; Aghahosseini, A.; Bogdanov, D.; Breyer, C. Job creation during a climate compliant global energy transition across the power, heat, transport and desalination sectors by 2050. Energy 2022, 238, 121690. [CrossRef] 